\title{
Nutritional evaluation and comparison study of seafoods such as fish and crayfish supplement dietary
}

\begin{abstract}
Seafoods dietary were excellent source of minerals such as calcium, iron. Zinc, potassium iodine, phosphorus, selenium, omega- 3 fatty acids and omega- 6 fatty acids wish are vital to Elderly and Pregnant women. Seafood prominently includes fish and shellfish, various species of mollusks, crustaceans, and echinoderms. The purpose of present study was to nutritional established and compared seafood such as fish and crayfish supplement dietary. The investigated recipe consisted of dietary formula $10 \%$ Fish+Nitrogen free $\operatorname{diet}(\mathrm{FINF}), 10 \%$ Crayfish+Nitrogen free diet (CFNF), $5 \%$ Fish $5 \%$ Crayfish+Nitrogen free $\operatorname{diet}(\mathrm{FCNF})$, Control diet(ANFE) Nitrogen free diet (NFD). The following parameters such as chemical composition, Nitrogen retention, Animal Bioassay and internal organs, were taking into consideration. The result revealed that there were growth responses in dietary were progressive in growth for FINF (46.55g-77.93g), CFNF (47-81.86g), FCNF (46.68-87.67g), ANFE (46.60$87.62 \mathrm{~g})$ respectively but NFE $(59.08-47.46 \mathrm{~g})$ dietary is decline in growth. Similar trend were followed by nitrogen retention, biological values, chemical composition, Nitrogen retention, Bioassay, internal organ. In conclusion Sea foods dietary promoted the rate of growth responses; biological values were comparable to that of white egg. Also, Seafoods experimented diets proved to be an excellent source of minerals which include calcium, iron, zinc, potassium iodine, phosphorus, selenium and omega-3 fatty acids wish are vital to Elderly, Pregnant women, feuto brain development and survival to their body growth. Seafood have better performance with elated attributes, could be used to combat depression, protein-energy malnutrition such as kwashiorkor and marasmus.
\end{abstract}

Keywords: processed seafood, crayfish, fish, nitrogen free diet
Volume 6 Issue I - 2018

\author{
Samson Ishola Ibironke,' Adefisola Bola \\ Adepeju, ${ }^{2}$ Olatunde Otutu, ${ }^{2}$ Damilola Sayo \\ Oyedele, ${ }^{2}$ Yetunde Oyebola Esan ${ }^{2}$ \\ 'Department of Food Science and Technology, Obafemi \\ Awolowo University lle-lfe, Nigeria \\ 2Department of Food Science and Technology, Joseph Ayo \\ Babalola University, Nigeria
}

Correspondence: Samson Ishola Ibironke, Department of Food Science and Technology, Faculty of Technology, Obafemi Awolowo University lle-Ife, Osun State, Nigeria, Email isolaibironke@yahoo.com

Received: November 29, 2017 | Published: January 24, 2018
Abbreviations: FINF, fish+nitrogen free diet; CFNF, crayfish+nitrogen free diet; NFD, nitrogen free diet

\section{Introduction}

Seafoods dietary were excellent source of minerals such as calcium, iron, zinc, potassium iodine, phosphorus, selenium, omega-3 fatty acids and omega- 6 fatty acids. Crayfish notable among the seafood otherwise known as crawfish, crawdads, freshwater lobsters, mountain lobsters, mudbugs or yabbies, are freshwater crustaceans resembling and small lobsters. ${ }^{1,2}$ They are regarded as members of the super families, Asteroidean and Parastacoidea. Fish are prominent among Seafoods and one of the most important sources of calcium. ${ }^{1-3}$ The soft bones of small fish such as sardines and smelts and canned varieties such as salmon are especially valuable sources of calcium. Other minerals in Seafood include zinc (oysters and crustaceans), iron (oysters, bluefish, and shrimp), copper (oysters, crabs, and lobster), potassium (mussels, scallops, and clams), and iodine, phosphorus, and selenium (all seafood in general). Generally, fresh Seafood is low in sodium hence it is beneficial for those who have to restrict the intake of sodium. Seafood is in nutrient including vitamins fat soluble (A, $\mathrm{D}, \mathrm{E}$, and $\mathrm{K}$ ) and water soluble ( $\mathrm{C}$ and the $\mathrm{B}$ complex. ${ }^{1-6}$ Vitamins $\mathrm{A}$ and $\mathrm{D}$ are found in fish liver oils and in small amounts in the fatty tissues of fish. Some fish oils, such as cod liver oil, are also very high in vitamin $\mathrm{D}$, providing more than $200 \%$ of the recommended intake in a single tablespoon. Seafood is reported generally low in fat and nutritional adequate for those who are obese and want to lose weight. Seafood is highly loaded with important nutrients, such as high protein and most especially when dried, Fish is also the world's best source of omega- 3 fatty acids and omega- 6 fatty acids, which function as building body and development of brain. In some quarter, pregnant women are medically advice to consume fish that are low in the food chain such as salmon, sardines, and trout. Fish consumption has been linked to reduced decline in brain function in old age. ${ }^{2,6-9}$ Seafood consumption regularly had been linked to having more grey matter in the brain centers that control memory emotion; eliminate depression which is common mental disorder, also connected to reduce risk of type 1 diabetes and several other autoimmune diseases. Some researcher has linked to lowering Asthma. Substantial evidence have it that omega-3 fatty acids supplied in Seafood may provide protection against this disease, reducing leading cause of vision impairment and blindness that mostly affects Elderly individuals. Some workers has reported that People taken Seafood have a much lower risk of developing macular degeneration, a leading cause of vision impairment and blindness In one study, regular consumption of fish was linked to a $42 \%$ lower risk of macular degeneration in women. ${ }^{7-10}$ Another study found that eating fatty fish once per week was linked to a $53 \%$ decreased risk of neovascular ("wet") macular 
degeneration. Sleep disorders have become incredibly common worldwide. $^{7-10}$ There are many different reasons for this (such as increased exposure to blue light), a meal with salmon fish taken three times per week has reported led to improvements in both sleep and daily functioning. The researchers speculated that this was caused by the vitamin D in the salmon fish. However, the aim of this study is to establish seafood nutrient composition, to highlight the superior biological value and outstanding medical succor to Elderly, Pregnant women and Children. ${ }^{7-10}$

\section{Materials and methods}

\section{Chemical analysis}

The chemical analysis included Protein (nitrogenx6.25), moisture, fat, crude fibre and carbohydrate of the ingredients, formulated diets and the protein contents of the internal organ were determined according to AOAC (2000). Energy value was determined using Combustion calorimeter, model e2K. ${ }^{1,3,6,11}$

\section{Experimental animal procedure}

Sixty white albinos ranged from $46.55-47.68 \mathrm{~g}$ were used in the experiment. They were between three to six weeks old, respectively. The experiment animals were weighed randomly selected and distributed into five groups of ten per group and was housed in a metabolic cage. They were fed on animal feeds (finisher) for seven days to acclimatize them to the new environment. The experimental animals were again reweighed and distributed into five groups of ten per group. $10 \mathrm{~g}$ of seafood supplements dietary were supply daily. Daily consumption of samples was carefully recorded and the weights were noted. Weight gain/loss of the experimental animals was taken every three days as graphical represented as Figure 1. Prior to the end of the experiment, which was twenty-eight days, the experimental animals were sacrificed. The organs collected from the animal including spleen, heart lungs kidney liver and small intestine were fixed immediately in $10 \%$ formyl saline for further experiment such as Nitrogen retention. ${ }^{12-15}$

\section{Ethical consideration}

Sixty white albino rats were approved for the experiment by the Animal Ethical Welfare Review Committee of the Obafemi Awolowo University, Osun State, Ile-Ife, Nigeria.

\section{Results and discussion}

Figure 1 showed the Growth rate and response to Animal experiment by Seafood Fish and Crayfish dietary and nitrogen free diet for 28days. The Figure 1 depicted the rate and growth responses in FINF are as follows (77.93-46.55g), CFNF (81.86-47g), FCNF (87.67-46.68g), ANFE (87.62-46.60g) Dietaries but NFE (47.46$59.08 \mathrm{~g}$ ) dietary decline in growth. This is because NFE is developed from maize (cereal) origin and reported deficient in two essential amino acids such as lysine and tryptophan hence could not support growth. ${ }^{16-19}$

Table1 revealed the Chemical composition of Seafood such as Fish and Crayfish dietary of the experimental animals Protein, Fat, Moisture, Ash, Fiber, CHO, Energy Kcal\% had the values 10.68$12.48 \%, 2.43-5.45 \%, 3.40-5.30 \%, 2.32-2.45,0 \% .76-0.88,75 \% .19-$ 89.49 and $279-393 \mathrm{Kcal} \%$ respectively. Protein content in the diet is enough to break down to amino acid, hence could provide enough and adequate nutrient to support growth while fat content is low and utilized by body. Fat content in the diet is very low therefore beneficial to obesity patient who want to lose weight; also the diet will be free from rancidity and keep longer. Moisture content met the recommend level of $5 \%$ and could inhibit the growth of microorganism and extent the shelf life of the diets. Ash, Fibre contents met the recommended level. Carbohydrate and Energy are higher enough to supply enough calories that will meet daily recommended for that is needed for the daily activities. ${ }^{3,7-11,19,20}$

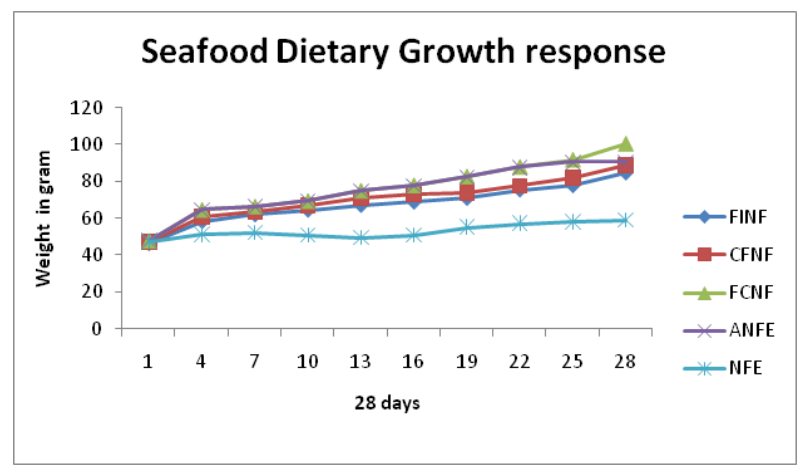

Figure I Growth Rate and response to animal experiment fed on Fish and Crayfish dietary supplement and nitrogen free diet for 28 days.

Foot Note: 10\%Fish+NFE (FINF), 10\%Crayfish+NFE (CFNF), $5 \%$ Fish $5 \%$ Crayfish+NFE (FCNF), Control diet (ANFE).

Table 2 indicates the various tissues of the internal organs of the experimental animal including Seafood Fish and Crayfish supplement dietary and growth response of the experimental animals for 28 days. The internal organs are liver, heart, right kidney and left kidney. Tissues of the internal organs showed the values ranged from 0.46$4.38 \mathrm{~g}, 0.37-0.43 \mathrm{~g}, 0.38-0.54 \mathrm{~g}$ and $0.37-0.54 \mathrm{~g}$ respectively. The internal organs of seafood Fish and Crayfish dietaries were similar in values $\mathrm{P}<0.05$ but NFE group internal were very small and about three times smaller than that of seafood Fish and Crayfish dietary. This is because NFE is developed from maize (cereal) origin and reported deficient in two essential amino acids such as lysine and tryptophan hence could not support growth. ${ }^{7-10,19,20}$

Table 3 reflected the Nitrogen retention in various tissues of the internal organ of Seafood such as Fish and Crayfish supplement dietary under the experimental animals for 28 days. Kidney $\mathrm{mg} / \mathrm{g}$, liver $\mathrm{mg} / \mathrm{g}$, muscle $\mathrm{mg} / \mathrm{g}$, feacal $\mathrm{mg} / \mathrm{g}$ and Urine $\mathrm{mg} / \mathrm{g}$ and their values were $20.20-70.04 \mathrm{mg} / \mathrm{g}, 20.05-70.61 \mathrm{mg} / \mathrm{g}, 10.30-70.78 \mathrm{mg} / \mathrm{g}, 0.62-$ $1.20 \mathrm{mg} / \mathrm{g}$ and $0.14-0.28 \mathrm{mg} / \mathrm{g}$. The Nitrogen retention of Seafood including Fish and Crayfish dietary were similar in values $\mathrm{P}<0.05$ but NFE group internal organ was about three times smaller than seafood Fish and Crayfish supplement dietary. This is because NFE diets lack protein that could break down to amino acid to increase rate of growth, to be utilized for body building and repair. This is because NFE is developed from maize (cereal) origin and reported deficient in two essential amino acids such as lysine and tryptophan hence could not support growth. ${ }^{7-10,19,20}$

Table 4 represented the bioassay of the experimental animal, bioassay of Seafood experimental dietary fed with Fish and Crayfish supplement and nitrogen free dietary. The biological values (BV \%), NPU\%, PER, FER, NPR were ranged from $85-89 \%$, 3.83, 3.80-4.90, 6.30-7.30 and 3.76-5.25 respectively. The Seafoods including Fish and Crayfish dietary biological values were found comparable to standard 
diet but diet NFE lacked biological value and not comparable. ${ }^{7-10,19,20}$ The biological values of BV \%, NPU\%, PER, FER, NPR were closer $85-88 / 100$ and similar to that of egg whites protein with a biological value of $88 / 100$. This may to due to fact that both seafood supplement dietary are from Animal protein sources but NFE diet lack biological value. NFE diet is a plant protein, lack essential protein that could break down to amino acid to be utilized for body repair and building. This is because NFE is developed from maize (cereal) origin and reported deficient in two essential amino acids such as lysine and tryptophan hence could not support growth..$^{7-10,19,20}$

Table I Chemical composition of seafood such as Fish and Crayfish dietary of the experimental animals

\begin{tabular}{llllllll}
\hline Diet & Protein\% & Fat\% & Moisture\% & Ash\% & Fiber\% & CHO\% & Energy K Cal\% \\
\hline FINF & $10.86^{\mathrm{a}} \pm 00$ & $5.45^{\mathrm{d}} \pm 03$ & $5.30^{\mathrm{c}} \pm 02$ & $2.32^{\mathrm{a}} \pm 03$ & $0.88^{\mathrm{b}} \pm 01$ & $75.19^{\mathrm{a}} \pm 00$ & $393^{\mathrm{b}} \pm 00$ \\
CFNF & $10.88^{\mathrm{a}} \pm 02$ & $3.84^{\mathrm{b}} \pm 02$ & $3.40^{\mathrm{a}} \pm 03$ & $2.45^{\mathrm{b}} \pm 04$ & $0.86^{\mathrm{b}} \pm 02$ & $78.57^{\mathrm{c}} \pm 01$ & $392^{\mathrm{b}} \pm 01$ \\
FCNF & $12.48^{\mathrm{b}} \pm 03$ & $3.45^{\mathrm{b}} \pm 02$ & $4.38^{\mathrm{b}} \pm 00$ & $2.34^{\mathrm{a}} \pm 02$ & $0.84^{\mathrm{b}} \pm 01$ & $76.49^{\mathrm{a}} \pm 02$ & $386^{\mathrm{a}} \pm 00$ \\
ANFE & $10.68^{\mathrm{a}} \pm 01$ & $4.80^{\mathrm{c}} \pm 00$ & $4.50^{\mathrm{b}} \pm 01$ & $2.40^{\mathrm{b}} \pm 00$ & $0.76^{\mathrm{a}} \pm 03$ & $76.68^{\mathrm{b}} \pm 03$ & $392^{\mathrm{b}} \pm 02$ \\
NFE & - & $2.43^{\mathrm{a}} \pm 01$ & $4.80^{\mathrm{b}} \pm 02$ & $2.36^{\mathrm{b}} \pm 01$ & $0.92^{\mathrm{c}} \pm 01$ & $89.49^{\mathrm{d}} \pm 01$ & $379^{\mathrm{a}} \pm 01$ \\
\hline
\end{tabular}

Foot Note: The data are mean \pm SD values of three determinations with different superscript in a column are significantly different $(P<0.05)$. $10 \%$ Fish $+N F E$ (FINF), $10 \%$ Crayfish+NFE (CFNF), 5\% Fish 5\%

Cray fish+NFE (FCNF), Control diet (ANFE).

Table 2 Various tissues of the internal organ of the experimental animal including Fish and Crayfish supplement dietary of the experimental animals for 28 days, the growth

\begin{tabular}{lllll}
\hline Diet & Liver(g) & Heart(g) & Kidney right(g) & Kidney Left(g) \\
\hline FINF & $4.38^{\mathrm{b}} \pm 01$ & $0.43^{\mathrm{b}} \pm 01$ & $0.48^{\mathrm{b}} \pm 00$ & $0.50^{\mathrm{b}} \pm 01$ \\
CFNF & $4.38^{\mathrm{b}} \pm 00$ & $0.43^{\mathrm{b}} \pm 01$ & $0.49^{\mathrm{b}} \pm 02$ & $0.52^{\mathrm{b}} \pm 02$ \\
FCNF & $4.38^{\mathrm{b}} \pm 02$ & $0.43^{\mathrm{b}} \pm 00$ & $0.48^{\mathrm{b}} \pm 00$ & $0.54^{\mathrm{b}} \pm 01$ \\
ANFE & $4.46^{\mathrm{c}} \pm 03$ & $0.48^{\mathrm{c}} \pm 02$ & $0.54^{\mathrm{c}} \pm 02$ & $0.52^{\mathrm{b}} \pm 00$ \\
NFE & $3.80^{\mathrm{a}} \pm 04$ & $0.37^{\mathrm{a}} \pm 03$ & $0.38^{\mathrm{a}} \pm 02$ & $0.37^{\mathrm{a}} \pm 03$
\end{tabular}

Foot Note:The data are mean \pm SD values of three determinations with different superscript in a column are significantly different $(P<0.05)$. $10 \%$ Fish $+N F E$ (FINF), $10 \%$ Crayfish+NFE (CFNF), 5\%Fish5\%Crayfish+NFE (FCNF), Control diet (ANFE).

Table 3 Nitrogen retention in various tissues of the internal organ of Fish and Crayfish supplement dietary of the experimental animals for 28 days, the growth

\begin{tabular}{llllll}
\hline Diet & Kidney mg/g & Liver mg/g & Muscle mg/g & Feacal mg/g & Urine mg/g \\
\hline FINF & $70.04^{\mathrm{b}} \pm 03$ & $70.08^{\mathrm{b}} \pm 02$ & $70.06^{\mathrm{a}} \pm 02$ & $0.62^{\mathrm{a}} \pm 01$ & $0.14^{\mathrm{a}} \pm 02$ \\
CFNF & $70.64^{\mathrm{b}} \pm 00$ & $70.61^{\mathrm{b}} \pm 03$ & $70.78^{\mathrm{b}} \pm 01$ & $0.80^{\mathrm{b}} \pm 00$ & $0.21^{\mathrm{b}} \pm 01$ \\
FCNF & $70.04^{\mathrm{b}} \pm 02$ & $70.08^{\mathrm{b}} \pm 00$ & $70.06^{\mathrm{a}} \pm 02$ & $0.62^{\mathrm{a}} \pm 02$ & $0.14^{\mathrm{a}} \pm 02$ \\
ANFE & $70.64^{\mathrm{b}} \pm 01$ & $70.61^{\mathrm{b}} \pm 00$ & $70.78^{\mathrm{b}} \pm 01$ & $0.80^{\mathrm{b}} \pm 00$ & $0.21^{\mathrm{b}} \pm 03$ \\
NFE & $20.20^{\mathrm{a}} \pm 02$ & $20.05^{\mathrm{a}} \pm 01$ & $10.30^{\mathrm{a}} \pm 02$ & $1.20^{\mathrm{c}} \pm 01$ & $0.28^{\mathrm{c}} \pm 04$ \\
\hline
\end{tabular}

Foot Note: The data are mean $\pm S D$ values of three determinations with different superscript in a column are significantly different $(P<0.05)$. The data are mean \pm SD values of three determinations with different superscript in a column are significantly different $(\mathrm{P}<0.05)$. I0\%Fish+NFE (FINF), I0\%Crayfish+NFE (CFNF), 5\%Fish5\%Crayfish+NFE (FCNF), Control diet (ANFE) [7-10,19].

Table 4 Bioassay of the experimental animal Bioassay BV \% NPU\% PER FER and NPR

\begin{tabular}{lllllll}
\hline Diet & BV \% & NPU\% & PER & FER & NPR & Gained/Loss \\
\hline FINF & $86^{\mathrm{a}} \pm 00$ & $3.83^{\mathrm{a}} \pm .01$ & $3.80^{\mathrm{a}} \pm 00$ & $6.3^{\mathrm{a}} \pm 00$ & $3.76^{\mathrm{a}} \pm .01$ & $38.27^{\mathrm{b}} \pm 00$ \\
CFNF & $88^{\mathrm{b}} \pm 02$ & $4.28^{\mathrm{b}} \pm .02$ & $4.50^{\mathrm{c}} \pm .03$ & $6.85^{\mathrm{b}} \pm 01$ & $4.28^{\mathrm{b}} \pm .02$ & $42.82^{\mathrm{c}} \pm 02$ \\
FCNF & $89^{\mathrm{b}} \pm 00$ & $5.25^{\mathrm{c}} \pm 00$ & $4.90^{\mathrm{c}} \pm .02$ & $7.30^{\mathrm{c}} \pm 00$ & $5.25^{\mathrm{c}} \pm .03$ & $52.59^{\mathrm{d}} \pm 00$ \\
ANFE & $85^{\mathrm{a}} \pm 01$ & $4.29^{\mathrm{a}} \pm 00$ & $4.20^{\mathrm{b}} \pm .01$ & $7.16^{\mathrm{c}} \pm .01$ & $4.23^{\mathrm{b}} \pm 02$ & $42.96^{\mathrm{c}} \pm 0.01$ \\
NFE & - & - & - & - & - & $-0.62^{\mathrm{a}} \pm 0.04$ \\
\hline
\end{tabular}

Foot Note:The data are mean \pm SD values of three determinations with different superscript in a column are significantly different (P<0.05). I0\%Fish+NFE (FINF), $10 \%$ Crayfish+NFE (CFNF), 5\%Fish5\%Crayfish+NFE (FCNF), Control diet (ANFE). 


\section{Conclusion}

Seafoods such as fish and crayfish supplement diets proved to be of animal protein origin contain complete amino acids that could be utilized for body system, repair and building. Biological values of Seafoods such as Fish and Crayfish supplement Dietary FINF, CFNF, FCNF, ANFE have biological values ranged from $85-88 \%$, comparable to egg white protein of $88 \%$, have complete amino acid profile, promoted the rate of animal experimented growth for 28 days and. In conclusion Seafoods supplement dietary have better performance attributes that could be used to combat depression, protein-energy malnutrition such as kwashiorkor and marasmus.

\section{Acknowledgements}

The authors are very grateful to staff of Central Science Laboratory Obafemi Awolowo University, Ile-Ife, Nigeria for making their laboratory conducive for teaching and research.

\section{Conflict of interest}

The author declares no conflict of interest.

\section{References}

1. AOAC. Official method of Analysis. 18th ed. Association of Officiating Analytical Chemists, Washington DC, USA; 2005.p. 935.14-992.24.

2. Titani K, Sasagawa T, Woodbury RG, et al. Amino acid sequence of crayfish (Astacus fluviatilis) trypsin If. Biochemistry. 1983;22(6):14591465.

3. Ibironke SI, Fashakin JB, Badmus OA. Nutritional Evaluation of Complementary Food Developed from Plant and Animal Protein Sources. Emerald Nutrition \& Food Science. 2012;42(2):111-120.

4. Delgado CL, Wada N, Rosegrant MW, et al. Fish to 2020. Supply and demand in changing global market. Washington DC, USA: International Food Policy Research Institute; 2003. p. 1-232.

5. FAO. Food and Agriculture Organization of the United Nations: Fisheries and Aquaculture Department. The state of world Aquaculture and Fisheries, Rome, Italy: FAO; 2007.

6. Oloyede FM, Oloyede FA, Obuotor EM, et al. Antioxidant activities and food value of five underutilized green leave vegetables in south western nigeria. The Nigerian Journal of Nutritional Science. 2011;32:13-18.

7. Sales J, Janssens GPJ. Nutrient requirements of ornamental fish. Aquatic Living Resources. 2003;16(6):533-540.
8. Seehausen O. African cichlid fish: a model system in adaptive radiation research. Proc Biol Sci. 2006;273(1597):1987-1998.

9. Worldfish Center. Fish: An Issue for Everyone. A Concept Paper for Fish for All; 2002. p. 1-14.

10. Ibironke SI, Ige MM, Adepeju AB. Haematological and In-Vivo study of moringa oleifera seed. MOJ Food Process Technol. 2017;4(6):00109.

11. Kuku A, Alabi MO, Ibironke SI. Effect of processing on the lectin and trypsin inhibitor content of Plukenetia conophora seeds as it affects growth performance and nutrient metabolism in rat. African Journal of Food Science. 2013;7(9):306-316.

12. Ibironke SI. Formulation of Infant weaning foods from vegetable proteins and cereal. American Journal of Food Technology. 2014;9(2):104-110.

13. Kuku A, Etti UI, Ibironke SI. Processing of Fluted Pumpkin Seeds, Telfairia Occidentalis (Hook F) As It Affects Growth Performance and Nutrient Metabolism in Rats. African Journal of Food and Agriculture Nutrition And Development. 2014;14(5):1992-2014.

14. Oladeji BS, Akanbi CT, Ibironke SI. Physico-chemical and nutritional evaluation of co-processed fermented yellow maize ogi (an infant diet) and carrot blends. Annals Food Science and Technology. 2014;15(1):8291.

15. Ibironke SI, Ige MM. Nutritional evaluation and chemical analysis of two commercial infant foods in South-Western, Nigeria. International Journal of Nutrition and Food Sciences. 2015;4(5):590-593.

16. Ibironke SI, Fawale O. Chemical analysis and animal bioassay of hildegardia barteri (Kariya Seed) Soy Bean and Maize. Annals Food Science and Technology. 2015;16(1):245-250.

17. Ibironke SI, Adepeju AB. Nutritional Assessment of Breakfast Foods Developed from Animal Polypeptide, Crayfish (Euastacus Spp) and Maize (Zea Mays). American Journal of Food and Nutrition. 2016;4(5):131-134.

18. Ibironke SI, Ige MM, Bejide RA. Histopathological and In-Vivo study of moringa oleifera seed. Annals. Food Science and Technology. 2016;17(1):102-108.

19. Oladeji BS, Irinkoyenikan OA, Gbadamosi SO, et al. Comparative analysis of physico-chemical properties and amino acids profile of three tropical maize hybrid cultivars in Nigeria. Emerald Nutrition \& Food Science. 2016;46(5):695-705.

20. Ibironke SI, Akinola EA, Adepeju AB. Comparative Study of Condiment Vegetable Basil Leaf (Ocimum gratissimum) and Bitter Leaf (Vernonia Amygdalina). American Journal of Food and Nutrition. 2017;5(3):95-98. 